\title{
Static analysis and strength calculation of drive shaft of large-scale cone crusher
}

\author{
V. V. Kondratenko, L. V. Sedykh*, A. Mirzakarimov, and A. Aleksakhin \\ National University of Science and Technology «MISIS», Moscow, Russian Federation
}

\begin{abstract}
The paper analyzes the causes of failures of coarse crushers “KKD 1500-180" at JSC “Almalyk MMC”. It has been established that the most common cause of these failures is a drive shaft failure. Static analysis of the strength of the drive shaft was performed using Autodesk Inventor 2020 CAD software. A dangerous shaft section was found, and recommendations aimed at improving its operability were proposed.
\end{abstract}

\section{Introduction}

At the present stage of the development of innovative technologies [1-15], it is necessary to conduct research aimed at improving the reliability of technological equipment [16-29]. Improvement of settlement and analytical and design solutions. One of the urgent tasks of modern mechanical repair production is to assess the load and deformations of various parts that are subject to frequent restoration, repair or new manufacture.

Extensive experience in operating large-size cone crushers "KKD 1500-180" at JSC “Almalyk Mining and Metallurgical Combine” indicates frequent equipment downtime due to emergencies associated with the loss of operability of large-sized parts. One of the problematic parts of this equipment is the drive shaft.

\section{Analytical calculations}

To identify the most loaded sections of the crusher drive shaft, a static analysis and strength analysis were performed using Autodesk Inventor 2020 software. Strength criterion is one of the most significant operability criterion of machine parts [30-40].

The initial data used for conducting static analysis:

- drive shaft of a step-type crusher with diameters from 158 to $200 \mathrm{~mm}$ and a length of $3121 \mathrm{~mm}$;

- $\quad$ mass of the drive shaft, $m=710 \mathrm{~kg}$;

- $\quad$ electric motor power $P=355 \mathrm{~kW}$;

- $\quad$ rotation speed $n=1500 \mathrm{rpm}$.

Rotational motion is transmitted from the electric motor through the clutch to the shaft, then the crusher's drum operates through the bevel gear.

Torque is determined by the formula:

* Corresponding author: lvsedykh@mail.ru 


$$
M_{r}=\frac{P}{\omega}=\frac{30 P}{\pi n}=\frac{30 \cdot 355}{3.1416 \cdot 1500}=2.26 \mathrm{kNm}
$$

where $\omega-$ is the angular velocity.

To carry out a static analysis, we determine the forces appearing on the shaft during rotation.

We calculate the forces acting from the clutch:

$$
\begin{gathered}
F^{\prime}{ }_{\tau}=\frac{M_{r}}{r_{c}}=\frac{2260}{0.25}=9040 \mathrm{~N} \\
F_{n}^{\prime}{ }_{n}=0.4 F^{\prime}{ }_{\tau}=3616 \mathrm{~N} \\
F^{\prime}=\sqrt{\left(F_{\tau}^{\prime}\right)^{2}+\left(F_{n}^{\prime}\right)^{2}}=9736 \mathrm{~N}
\end{gathered}
$$

We determine the forces on the shaft section under the gear:

$$
\begin{gathered}
F "_{\tau}=\frac{M_{r}}{r_{g}}=\frac{2260}{0.405}=5580 \mathrm{~N} \\
F_{n}^{\prime \prime}=0.4 F{ }_{\tau}{ }_{\tau}=2233 \mathrm{~N} \\
F^{\prime \prime}=\sqrt{\left(F{ }_{\tau}\right)^{2}+\left(F n_{n}\right)^{2}}=6010 \mathrm{~N}
\end{gathered}
$$

We constitute the equations of forces equilibrium and determine the prop reactions $R^{\prime}$ and $R^{\prime \prime}$ (figure 1):

$$
\begin{gathered}
\sum M_{y}{ }_{y}=R^{\prime} \cdot 1.805-m g \cdot 0.9025+F_{n}{ }_{n} \cdot 0.3325-F_{n}{ }_{n} \cdot 2.536=0 \\
R^{\prime}=1190 \mathrm{~N} \\
\sum M_{y}{ }_{y}=-R^{\prime \prime} \cdot 1.805+m g \cdot 0.9025+F_{n}{ }_{n} \cdot 2.1375-F_{n}^{\prime} \cdot 0.731=0 \\
R "=7591 \mathrm{~N}
\end{gathered}
$$

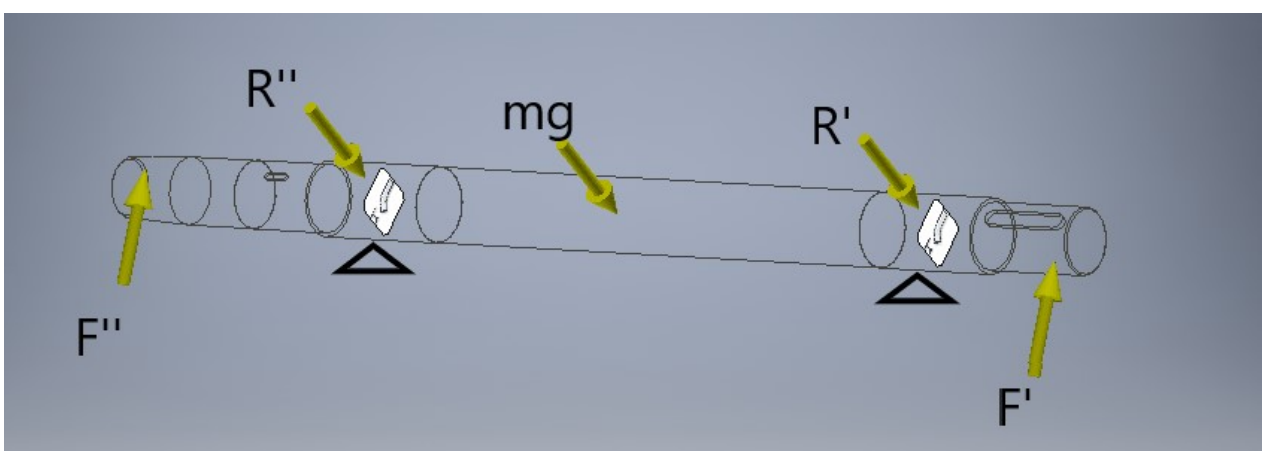

Fig. 1. Forces acting on the shaft.

We will verify the correct determination of forces:

$$
m g+R^{\prime \prime}+R^{\prime}-F^{\prime \prime}+F^{\prime}=0
$$




$$
6965+7591+1190-6010+9736=0
$$

The equilibrium condition is satisfied, therefore, we can further use the calculated forces acting on the shaft for static analysis.

\section{CAE calculations}

The result of calculating the stresses according to Mises is presented in figure 2.

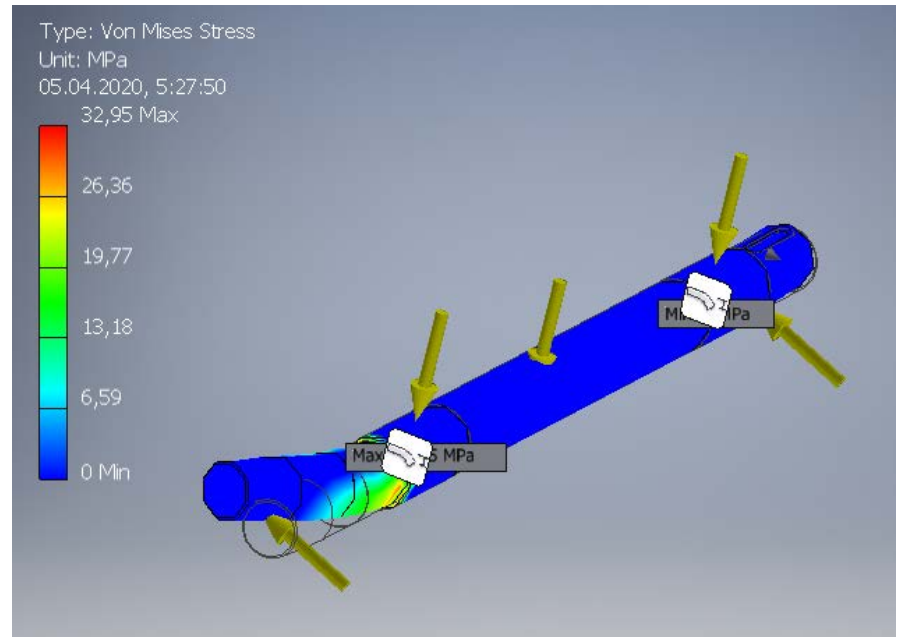

Fig. 2. Von Mises stress.

Figure 3 shows the maximum displacement of drive shaft.

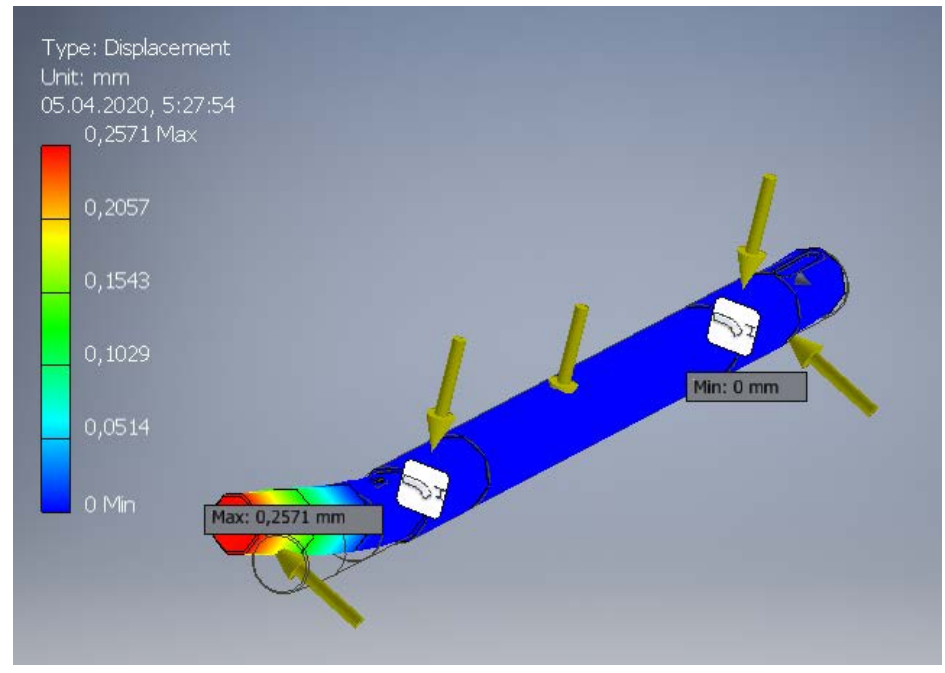

Fig. 3. Displacement.

Figure 4 shows the equivalent deformation. 


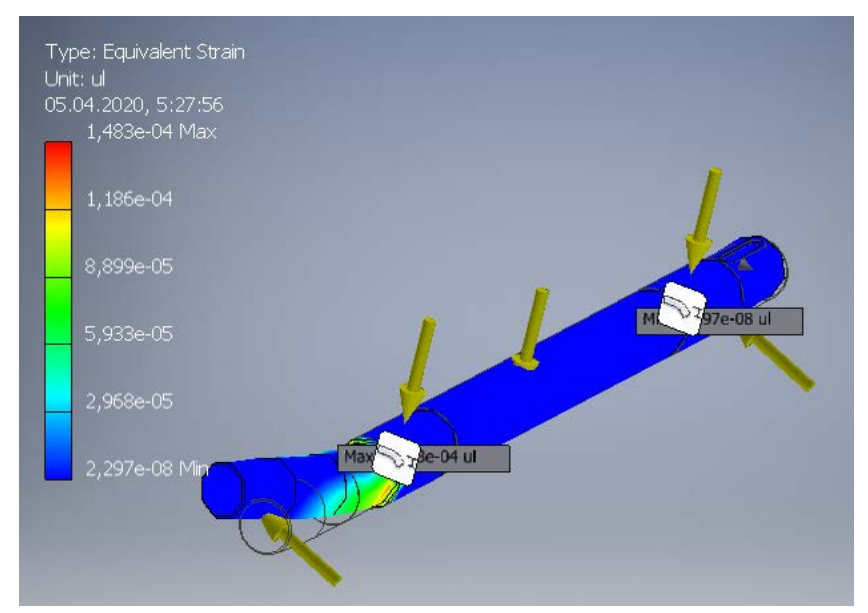

Fig. 4. Equivalent strain.

The numerical results of the analysis performed in Autodesk Inventor 2020 are presented in the table 1 .

Table 1. Crusher drive shaft static analysis results

\begin{tabular}{|c|c|c|}
\hline Name & Minimum & Maximum \\
\hline Volume & \multicolumn{2}{|c|}{$90494800 \mathrm{~mm}^{3}$} \\
\hline Mass & \multicolumn{2}{|c|}{$710,384 \mathrm{~kg}$} \\
\hline Von Mises Stress & $0,00450251 \mathrm{MPa}$ & $32,9513 \mathrm{MPa}$ \\
\hline 1st Principal Stress & $-5,99087 \mathrm{MPa}$ & $32,5363 \mathrm{MPa}$ \\
\hline 3rd Principal Stress & $-39,0433 \mathrm{MPa}$ & $2,60024 \mathrm{MPa}$ \\
\hline Displacement & $0 \mathrm{~mm}$ & $0,257126 \mathrm{~mm}$ \\
\hline Safety Factor & $10,6217 \mathrm{ul}$ & $15 \mathrm{ul}$ \\
\hline Stress XX & $-32,4949 \mathrm{MPa}$ & $32,3698 \mathrm{MPa}$ \\
\hline Stress XY & $-6,23733 \mathrm{MPa}$ & $11,9029 \mathrm{MPa}$ \\
\hline Stress XZ & $-5,47142 \mathrm{MPa}$ & $17,3469 \mathrm{MPa}$ \\
\hline Stress YY & $-12,2677 \mathrm{MPa}$ & $6,76512 \mathrm{MPa}$ \\
\hline Stress YZ & $-1,73897 \mathrm{MPa}$ & $2,00225 \mathrm{MPa}$ \\
\hline Stress ZZ & $-12,3199 \mathrm{MPa}$ & $6,42019 \mathrm{MPa}$ \\
\hline X Displacement & $-0,0415655 \mathrm{~mm}$ & $0,0416311 \mathrm{~mm}$ \\
\hline Y Displacement & $-0,00227041 \mathrm{~mm}$ & $0,0892219 \mathrm{~mm}$ \\
\hline Z Displacement & $-0,000196482 \mathrm{~mm}$ & $0,23855 \mathrm{~mm}$ \\
\hline Equivalent Strain & $0,0000000229683 \mathrm{ul}$ & $0,0001483 \mathrm{ul}$ \\
\hline 1st Principal Strain & $0,0000000102571 \mathrm{ul}$ & $0,000155541 \mathrm{ul}$ \\
\hline 3rd Principal Strain & $-0,00016906 \mathrm{ul}$ & $-0,0000000181391 \mathrm{ul}$ \\
\hline Strain XX & $-0,000150454 \mathrm{ul}$ & $0,000154466 \mathrm{ul}$ \\
\hline Strain XY & $-0,0000402308 \mathrm{ul}$ & $0,0000767734 \mathrm{ul}$ \\
\hline Strain XZ & $-0,0000352906 \mathrm{ul}$ & $0,000111888 \mathrm{ul}$ \\
\hline Strain YY & $-0,000035485 \mathrm{ul}$ & $0,0000374621 \mathrm{ul}$ \\
\hline Strain YZ & $-0,0000112163 \mathrm{ul}$ & $0,0000129145 \mathrm{ul}$ \\
\hline Strain ZZ & $-0,0000464921 \mathrm{ul}$ & $0,0000438258 \mathrm{ul}$ \\
\hline
\end{tabular}




\section{Summary}

The paper presents the results of a study aimed at improving the operability of crushers using CAD. In accordance with the results obtained, it was found that the neck of the shaft, in the place where the liner is installed, is a dangerous section.

It is proposed to change the shaft design, increasing the diameter of the shaft in its dangerous section and thereby increasing its strength.

It is recommended to significantly reduce interruptions in the operation of crushers, since when starting and stopping the machine there are uneven peak loads that reduce its strength.

\section{References}

1. Bratan S and Roshchupkin S 2018 Synthesis of lunberger stochastic observer for estimation of the grinding operation state MATEC Web of Conferences 22401133. DOI: $10.1051 /$ matecconf/201822401133

2. Roshchupkin S and Kharchenko A 2018 Method of building dynamic relations, estimating product and grinding circle shape deviations MATEC Web of Conferences 224 01001. DOI: 10.1051/matecconf/201822401001

3. Bratan S, Roshchupkin S and Revenko D 2017 Probabilistic Approach for Modeling Electroerosion Removal of Grinding Wheel Bond Procedia Engineering 206 pp 142631. DOI: 10.1016/j.proeng.2017.10.656

4. Bardovsky A D, Gerasimova A A and Basyrov I I 2019 Study of oscillating process of harp screens Lecture Notes in Mechanical Engineering 0(9783319956299) pp 133-139. DOI: 10.1007/978-3-319-95630-5_14

5. Gorbatyuk S, Kondratenko V and Sedykh L 2019 Influence of critical speed when working shafts with asymmetrically located monolithic weighting on the accuracy of work surfaces Materials Today: Proceedings 19 pp 2117-20. DOI: 10.1016/j.matpr.2019.07.222

6. Bardovsky A D, Gerasimova A A and Basyrov I I 2020 Constructive solutions for upgrading of the drive of processing equipment IOP Conference Series: Materials Science and Engineering 709(2) 022015. DOI: 10.1088/1757-899X/709/2/022015

7. Gorbatyuk S, Kondratenko V and Sedykh L 2019 Influence of critical speed when working shafts with symmetrically located monolithic weighting on the accuracy of work surfaces Materials Today: Proceedings 19 pp 2361-64. DOI: 10.1016/j.matpr.2019.07.695

8. Chichenev N A 2015 Import-replacing re-engineering of the drive of the rollers in the intermediate roller table of a continuous bloom caster Metallurgist 58(9-10) pp 892-895. DOI: 10.1007/s11015-015-0013-9

9. Gerasimova A A, Radyuk A G and Glukhov L M 2014 Applying Coatings to the Narrow Walls of Continuous-Caster Molds to Improve the Quality of the Surface of Slabs Metallurgist 58(5-6) pp 397-400. DOI: 10.1007/s11015-014-9922-2

10. Gerasimova A A, Radyuk A G and Titlyanov A E 2016 Wear-resistant aluminum and chromonickel coatings at the narrow mold walls in continuous-casting machines Steel in Translation 46(7) pp 458-462. DOI: 10.3103/S0967091216070068

11. Gerasimova A, Mishedchenko O and Devyatiarova V 2020 Determination of temperature conditions for steel plate rolling at Vyksa Steel Works (AO VMZ) IOP Conference Series: Materials Science and Engineering 709(2) 022016. DOI: 10.1088/1757899X/709/2/022016

12. Keropyan A, Gorbatyuk S and Gerasimova A 2017 Tribotechnical Aspects of Wheel-Rail System Interaction Procedia Engineering 206 pp 564-569.

DOI: 10.1016/j.proeng.2017.10.517 
13. Kobelev O A, Albul S V and Kirillova N L 2020 Research and development of broaching methods on mandrel of large-sized pipe forgings IOP Conference Series: Materials Science and Engineering 709(4) 044104. DOI: 10.1088/1757-899X/709/4/044104

14. Gorbatyuk S M, Morozova I G and Naumova M G 2017 Reindustrialization principles in the heat treatment of die steels Steel in Translation 47(5) pp 308-312. DOI: 10.3103/S0967091217050047

15. Gorbatyuk S, Kondratenko V (2) and Sedykh L 2019 Investigation of the Deep Hole Drill Stability When Using a Steady Rest Materials Today: Proceedings 11 pp 258-264. DOI: 10.1016/j.matpr.2018.12.140

16. Gorbatyuk S, Pashkov A and Chichenev N 2019 Improved Copper-Molybdenum Composite Material Production Technology Materials Today: Proceedings 11(1) pp 3135. DOI: 10.1016/j.matpr.2018.12.102

17. Gerasimova A A, Keropyan A M and Girya A M 2018 Study of the Wheel-Rail System of Open-Pit Locomotives in Traction Mode Journal of Machinery Manufacture and Reliability 47(1) pp 35-38. DOI: 10.3103/S1052618818010065

18. Keropyan A M 2016 Features of interaction of traction wheels of an electric locomotive and a diesel locomotive with rails in the conditions of open mountain works Journal of Friction and Wear 37(1) pp 78-82. DOI: 10.3103/S1068366616010074

19. Gorbatyuk S M, Pashkov A N, Zarapin A Y and Bardovskii A D 2019 Development of Hot-Pressing Technology for Production of Aluminum-Based Metal-Matrix Composite Materials Metallurgist 62(11-12) pp 1261-66. DOI: 10.1007/s11015-019-00784-0

20. Keropyan A M, Gorbatyuk S M, Bibikov P Y and Bardovski A D 2019 Influence of Roughness of Working Surfaces of the Wheel-Rail System of Open-Pit Locomotives with an Implementable Adhesion Coefficient Journal of Friction and Wear 40(1) pp 7379. DOI: $10.3103 /$ S1068366619010082

21. Bibikov P Y, Bardovskiy A D and Keropyan A M 2019 Investigation of press classification process of weak rocks Materials Today: Proceedings 19 pp 2552-54. DOI: 10.1016/j.matpr.2019.08.207

22. Gerasimova A, Gorbatyuk S and Devyatiarova V 2018 Application of gas-thermal coatings on low-alloyed steel surfaces Solid State Phenomena 284 SSP pp 1284-90. DOI: 10.4028/www.scientific.net/SSP.284.1284

23. Gorbatyuk S, Kondratenko V and Sedykh L 2018 Tool stability analysis for deep hole $\begin{array}{lllll}\text { drilling } & \text { MATEC } & & \\ & \end{array}$ DOI: 10.1051/matecconf/201822401035

24. Gorbatyuk S M and Sedykh L V 2010 Improving the durability of rolling-mill rolls Metallurgist 54(5-6) pp 299-301. DOI: 10.1007/s11015-010-9297-y

25. Bast J, Gorbatyuk S M, Kryukov I Yu 2011 Horizontal hcc-12000 unit for the continuous casting of semifinished products Metallurgist 55(1-2) pp 116-118. DOI: 10.1007/s11015011-9399-1

26. Gorbatyuk S M, Pavlov V M, Shapoval A N and Gorbatyuk M S 1998 Experimental use of rotary rolling mills to deform compacts of refractory metals Metallurgist 42(5-6) pp 178-183. DOI: 10.1007/BF02766359

27. Naumova M G, Morozova I G, Zarapin A Y and Borisov P V 2018 Copper alloy marking by altering its surface topology using laser heat treatment Metallurgist 62(5-6) pp 464469. DOI: $10.1007 / \mathrm{s} 11015-018-0682-2$

28. Glukhov L M, Gorbatyuk S M, Morozova I G and Naumova M G 2016 Effective Laser Technology for Making Metal Products and Tools Metallurgist 60(3-4) pp 306-312. DOI: 10.1007/s11015-016-0291-X

29. Bardovskii A D, Gerasimova A A, Keropyan A M and Bibikow P Y 2018 Influence of the mechanical characteristics of harp screen material on screening process Izvestiya Ferrous Metallurgy 61(9) pp 678-682. DOI: 10.17073/0368-0797-2018-9-678-682 
30. Busygin A M 2018 The force analysis of the caterpillar excavator stick arrangement mechanism with three degrees of freedom Mining Informational and Analytical Bulletin 2018(1) pp 133-142. DOI: 10.25018/0236-1493-2018-1-0-133-142

31. Efremov D B, Gerasimova A A, Gorbatyuk S M and Chichenev N A 2019 Study of kinematics of elastic-plastic deformation for hollow steel shapes used in energy absorption devices CIS Iron and Steel Review $\mathbf{1 8}$ pp 30-34. DOI: 10.17580/cisisr.2019.02.06

32. Zakharov A N, Gorbatyuk S M and Borisevich V G 2008 Modernizing a press for making refractories Metallurgist 52(7-8) pp 420-423. DOI: 10.1007/s11015-008-9072-5

33. Gorbatyuk S M and Kochanov A V 2012 Method and equipment for mechanically strengthening the surface of rolling-mill rolls Metallurgist 56(3-4) pp 279-283. DOI: $10.1007 / \mathrm{s} 11015-012-9571-2$

34. Gorbatyuk S M, Morozova I G and Naumova M G 2017 Development of the working model of production reindustrialization of die steel heat treatment Izvestiya Ferrous Metallurgy 60(5) pp 410-415. DOI: 10.17073/0368-0797-2017-5-410-415

35. Gorbatyuk S M, Osadchii V A and Tuktarov E Z 2011 Calculation of the geometric parameters of rotary rolling by using the utomated design system autodesk inventor Metallurgist 55(7-8) pp 543-546. DOI: 10.1007/s11015-011-9465-8

36. Keropyan A and Gorbatyuk S 2016 Impact of Roughness of Interacting Surfaces of the Wheel-Rail Pair on the Coefficient of Friction in their Contact Area Procedia Engineering 150 pp 406-410. DOI: 10.1016/j.proeng.2016.06.753

37. Radyuk A G, Gorbatyuk S M and Gerasimova A A 2011 Use of electric-arc metallization to recondition the working surfaces of the narrow walls of thick-walled slab molds Metallurgist 55(5-6) pp 419-423. DOI: 10.1007/s11015-011-9446-y

38. Kartsov S K, Kupriyanov D Y, Polyakov Y A and Zykov A N 2020 Non-local Means Denoising Algorithm Based on Local Binary Patterns Intelligent Systems Reference Library 182 pp. 153-164. DOI: 10.1007/978-3-030-39177-5_12

39. Jordan D W and Smith P 2007 Nonlinear Ordinary Differential Equations: An Introduction for Scientists and Engineers (Oxford: Oxford University Press)

40. Naumova M G, Basyrov I I and Aliev Kh B 2018 Reengineering of the ore preparation production process in the context of «almalyk MMC» JSC MATEC Web of Conferences 224 01030. DOI: 10.1051/matecconf/201822401030 